\title{
Debt Covenants and Accounting Conservatism
}

\author{
Adamu Pantamee Abdurrahman ${ }^{1}$, Shafi Mohamad ${ }^{1}$, Ooi Chee Keong ${ }^{1} \&$ Syed Ehsanullah $^{2}$ \\ ${ }^{1}$ School of Accounting \& Finance, Faculty of Business \& Law, Taylors University, Malaysia \\ ${ }^{2}$ Tunku Puteri Intan Safinaz School of Accountancy, Universiti Utara Malaysia, Malaysia \\ Correspondence: Ooi Chee Keong, School of Accounting \& Finance, Faculty of Business \& Law, Taylors University, \\ Malaysia.
}

Received: December 15, 2019

Accepted: February 2, 2020

Online Published: July 15, 2020

doi:10.5430/ijfr.v11n4p537

URL: https://doi.org/10.5430/ijfr.v11n4p537

\begin{abstract}
The purpose of this study is to examine the association between debt covenants and accounting conservatism. The study uses the data of 180 non-financial listed companies on the Malaysian Stock Exchange during the period of 2008 to 2018. Our findings suggest that the increasing use of debt covenants automatically gears up the firm to focus on the timely recognition of loss in order to satisfy the debt market. Further, we also examine whether there is a relationship between those firms' that are more dependent on debt covenants and timely recognition of losses. This study finds that as the firm depends more on covenants their emphasis on the timely recognition of economic loss increases to avoid potential debt market issues. We also discuss the transfer of controls and power to the bondholders in a situation of financial distress and the auditor's responsibility to monitor the limitations of accounting conservatism.
\end{abstract}

Keywords: debt covenants, accounting conservatism, recognition of loss, bondholders, shareholders, agency conflict

\section{Introduction}

The imposition of accounting conservatism following the introduction of debt covenants is frequently touched upon in the accounting literature. Prior studies report that accounting conservatism is one of the mechanisms to remove potential conflicts between bondholders and shareholders and has also contributed to development of the debt market (Zhong \& Li 2017). However, since debt covenants are based on accounting numbers, the introduction of accounting conservatism helps to mitigate the conflict between bondholders and shareholders (Christensen et al., 2016). Hence, the importance of conservatism when developing debt covenants. Previous studies found a lot of evidence showing that accounting conservatism permits the acceptance of debt covenant in order to protect bondholders' wealth. The background to this study is based on an earlier study by Nikolaev(2010) and the sample data is collected from the annual reports of Malaysian listed companies.

This study investigates the conflicts faced by firms whose public debt contracts are based on covenants which practice the timely recognition of economic losses in earnings in accordance with the principles of accounting conservatism. Debt contracting is the best example in practice regarding the application of accounting conservatism (Balakrishnan et al., 2016). Accounting conservatism helps to mitigate the differences between bondholders and shareholders (Ruch \& Taylor 2015). It also facilitates bondholders in taking over the managerial decision-making powers using the covenant, whenever their economic interests are at stake (Kim \& Zhang 2016). It has been shown by several different empirical studies that debt covenants rely on the degree of accounting conservatism employed by the firm. It is the responsibility of debt markets to examine this relationship in order to protect bondholders. However, often in practice bondholders fail to get timely information, hence have no opportunity to monitor managerial activities, and therefore end up having weaker control over the operations. Therefore, public bondholders have a greater need for timely acknowledgement of issues related to recognition of losses when compared to banks, financial institutions and other private lenders (Deng et al., 2018). In situations when firms are going through economic distress, debt covenants would be the mechanism that limit the managers' power to expropriate bondholders' wealth. Usually, managers expropriate the wealth by making unnecessary distributions to the shareholders, issuance of priority debt claims and investing in projects which have a negative appraisal (Hu \& Jiang (2019). These actions by the covenant holders are legally binding in situations where the performance of firms have deteriorated significantly. Covenants can be utilized more efficiently if information is received in a timely manner so 
that action can be taken to recognize losses in the books accordingly. Timely information also enables the bondholders to resist opportunistic actions taken by management during times of distress with the help of covenant binding. Covenants also assist the accounting system by pursuing the timely recognition of economic losses in accounting earnings (Kim, 2019). In addition, although covenants are not always able to protect the expropriation of earnings by bondholders, there are other elements as well that could be prevented by covenants.

In Malaysia, it was found that the opportunistic behavior of dominant shareholders can be best controlled by accounting conservatism. Many prior studies found accounting conservatism to be an important mechanism to control dominant shareholders ( $\mathrm{Li}$ et al., 2015). Malaysia is a high ownership concentration economy where around $31 \%$ of listed companies are owned by individual shareholders and around $62 \%$ are owned by the five largest shareholders. In this type of environment bondholders face insecurities as the shareholders are more powerful and managements must work under supervision of the board (Saeed, 2018). Debt covenants are used as a control mechanism in these situations to protect the bondholders' wealth and safeguard their rights.

The traditional definition of accounting conservatism is the practice of an accounting system that anticipates all losses but recognizes no profits until realized (Le et al., 2017). Accounting conservatism is the unreliable projection of earnings that requires extensive verification to realize good news as gains and bad news as losses (Kim \& Zhang (2016). Financial Accounting Standards Board (FASB) guidelines requires that valuation of assets and liabilities of firms are carried out on regular bases in order to check for uncertainties whereby the management can apply some discretion within the framework of accounting standards. Some previous studies argue that financial information is biased due to the application of conservative accounting (Charitou et al., 2018), however some researchers suggest that it is one of the best tools for governance mechanism. The main objective of accounting conservatism is to limit the opportunistic behavior of managers and facilitate the firm in increasing stock value and protecting the minority shareholders. Ownership concentration can also act to influence the information to be disclosed in financial reports (Callen et al., 2018). Several scholars have noted that if the agency conflict is mitigated by the presence of large shareholders through close monitoring than shareholders are not keen to rely on financial reporting. Therefore, they are not interested in following the practice of conservative accounting (Lara et al., 2016). Hence, in such situations, if there are any bondholders in the firm, they must safeguard their wealth with the use of debt covenants. In addition, most shareholders are not interested in adopting rigid accounting conservatism as they feel insecure because of the threat posed by expropriation activities.

There are two other factors that management needs to be aware of when managing debt covenants. First is maintaining the good reputation of the firm in order to get access to public debt markets at favorable interest rates (Kim, 2019). Second is the timely recognition of losses in the books in order to avoid litigation (Xie, 2015). As debt covenants are closely tied to bondholders, they are likely to pay incentives to management and auditors if they work in favor of bondholders. The timely recognition of losses by management will help bondholders to effectively utilize the covenant. These covenants require auditors to certify compliance making them legally responsible for the covenant. Therefore, auditors should be more cautious and focused on the application of conservatism in the presence of accounting-based covenants.

\section{Hypothesis Development}

When financial position of companies approaches a potential distress situation, the vulnerability of bondholders' increases in response to opportunistic actions taken by management and shareholders (Wang \& Zhang 2017). The agency conflict arises between shareholders and bondholders when making strategic decisions like asset substitution, debt overhang and claim dilution (Donovan et al., 2015). These kinds of conflicts exacerbate the financial decision-making process and create difficulties for the relationship between shareholders and bondholders (Khurana \& Wang (2015). Hence the covenant that restrict managers ability to pay dividends, to take on extra debt and invest in non-feasible projects in the absence of bondholders. The function of covenants is to limit the ability of managers to undertake actions that can potentially hurt bondholders' wealth. The process of dividend distribution can be restricted by covenants, and covenants can effectively lever the firm to use cash flows in such a way that releases the firm from potential debt overhanging situations. In such situation's managers are not willing to take on even positive NPV projects because it will exacerbate the debt to equity ratio. There are other covenants that restrict mergers with other businesses or acquisition of other businesses or disposal of assets which represent asset substitutions. Whereas the restriction on lease and sales-and-leaseback decisions and negative pledge covenants are examples of claims dilution. Covenants are not meant merely for financially unstable companies, they can also become binding for financially stable companies. They provide the vehicle to restrain managers' ability to make wrongful decisions that can hurt the firm's value. Moreover, in cases where significant cost arises due to technical default and the required 
renegotiation, covenant restriction may lead to the eventual disposal of assets if the productivity of assets is not beneficial (Pittman \& Zhao 2019). Therefore, firms must evaluate the costs and benefits of using covenants before signing them on (De Franco et al., 2016).

The efficiency of debt covenants can be enhanced by the timely recognition of losses in two ways:

- By transferring decision rights to bondholders.

- By the signaling role of covenants.

Timely loss recognition which is a feature of accounting conservatism and a component of accounting quality, plays an important role in enhancing the efficiency of covenants (Xie, 2015). The earlier losses are recognized the timelier that constraints can be put in place in order to avoid the expropriation of firm's value during periods of poor economic conditions. The main concern of bondholders is to shield the firm from the opportunistic behavior of managers and try to minimize the agency costs related to debt in a timely fashion before the disclosure of negative economic news by the accountants. The limitation of covenants is that they are usually based on accounting information and mainly concerned with reported earnings, values of asset, values of liabilities and the makeup of equity. When a firm reaches the stage of financial distress, the bondholders depend on timely recognition of losses in order to take control of key firm decisions and this applies even more so when contracts of the firm are bound by covenants. It is argued that covenants should not be strongly bound with accounting information because timely recognition of losses can resolve agency problems as it motivates managers to recognize future losses in advance arising from non-profitable investments (Suleiman, 2017). Therefore, covenants can be effectively used if losses are recognized in a timely manner that enables bondholders to control management actions and thereby save their money.

Prior studies examined the relationship between conservatism and debt contracting. The results varied from economy to economy as those markets that depend on public debt are more sensitive and require the early recognition of losses in order to sustain the confidence of bondholders (Collins et al., 2017). The extra benefits of conservatism are that it helps to reduce the cost of debt, enhance the reliability of information and facilitate the early transfer of control rights (Biddle et al., 2016).

The signaling value of covenants has a correlation with timely loss recognition as it can be improved if the loss recognition happens on time. The combination of conservative reporting and covenants can be shown to be the optimal contracting mechanism (Glover \& Lin 2018). A prior researcher used a model in which a firm needed debt financing, it had to make two contracts, the first contract with the managers for compensation and a second contract with the lenders for debt. The main objective of compensation contracts is to align the managerial incentives with the covenant. In the absence of covenants, firms that apparently have low risk of default used to plan their incentive packages to be less than optimal in order to signal their position to investors, thus trying to engage them using the market distortion technique. Therefore, signaling costs will not be incurred if debt covenants are prepared based on earnings and the earnings is measured using conservative accounting methods.

There is inconclusive evidence in the literature regarding the importance of managerial incentives in order to manage earnings up to the level of the covenant threshold (Deslatu \& Susanto 2018). The general impression conveyed by firms is that they are in less trouble when ready to hit the covenant threshold. However prior research found evidence in which firms argued that financial distress occurred due to the wrong accounting choices of managers, hence holding the managers responsible for the threat of litigation and cutting their incentives in order to increase earnings so as to maintain the covenant threshold (Chen et al., 2018). Economic losses are usually anticipated by the stock market and thus reflected in share values. At times this forward anticipation makes it difficult for managers to justify their incentives. For anything other than accounting-based contracts, the relevant stakeholders are not concerned with the timely recognition of pre-anticipated economic losses. Moreover, the contracting parties have nothing to do with regards to the timeliness of recording accounting transactions related to the recognition of losses in financial statements.

There is an argument in the market that the demand for timely loss recognition is not just only for the debt market, but it is also enforced by auditors to conservatively comply with the covenant. This is the requirement of accounting conservatism to record the impairment of assets and other accruals that can create a negative impact on the stock value of the firm and especially in relation to future cash flows of the firm. It is generally known that accounting does not accord the same treatment for gains and losses with respect to timely disclosures. However, timely treatments are sometime difficult for managers to adhere to, but it is suggested by scholars that the incentives of managers should be aligned with the timely recognition of losses in order to comply with the covenant. 
The most important factor to ensure that companies adhere with the policies of accounting conservatism is to enhance the market reputation. The market reputation is the key to access the public debt market and if the manager's reputation is also aligned with the firm's reputation, when the firm's reputation is affected, it will also negatively affect the manager's reputation. So, the untimely reported loss will affect both reputation of the firm and as well as the managers and create significant difficulties in future when trying to access the public debt market (Marín Salazar \& Ilić 2018). Hence, reputation is the tool that improves the contracting efficiency of debt covenants. Moreover, management should be rewarded for timely recognition of losses especially when firms are willing to breach the debt contract (Hillier et al., 2018).

Another factor promoting timely loss recognition is the threat of litigation. In such scenarios where default approaches, the litigation threat directly targets the auditors (Hope et al., 2017). The main issue is that the lack in disclosure of bad news would become the basis to increase the firm's legal liability (Marín Salazar \& Ilić 2018). In addition, there is an obligation for the auditors of borrowing firms to provide the certificate of compliance that attests to no breach of covenant during the year (Kim, 2019). Therefore, auditors would be liable for the litigation risk, if the firm fails to recognize its negative economic news. Prior studies reported that if a firm is declared as a defaulter than the litigation risk will increase, the audit plan will have to be revised and this will require the issuance of modified opinions (Bhaskar et al., 2017). Hence the debt covenant is dependent on accounting information which needs to be driven by a high degree of conservatism and overseen by the auditors.

\section{Hypothesis}

As noted in previous studies, efficiency of the contracting role of covenants is increased by timely recognition of losses. This also helps in resolving agency conflicts between shareholders and bondholders. Therefore, it is to be expected that there must be a positive relationship between timely loss recognition and the existence of debt covenants. Similarly, the function of covenants is to adjust the accounting numbers according to the requirements of bondholders. In this context, the association between covenants and timely recognition does not exist. Thus, the development of our new hypothesis as follows:

Hypothesis H1: The incremental use of debt covenants is directly proportional to the timely recognition of losses by the firm.

The precise relationship between covenants and timely loss recognition is still unresolved. Hence the question whether a conservative firm should rely on covenants or seek alterations to the degree with which the loss is recognized? It is difficult to settle this argument, as this action requires a legal instrument that is impossible to obtain. In this context, firms should use their own controls to verify the debt issues happening due to the lack of timely recognition of losses. Hence, we conclude that the responsibility for timely recognition of losses increases when the firm is about to enter new debt contracts. Thus, the development of our new hypothesis is as follows:

Hypothesis H2: Firms that rely more on debt covenants, emphasize more the timely recognition of losses in order to handle the debt issues.

\section{Research Method}

In this study we use timely recognition of losses as the proxy for accounting conservatism and this will correlate with debt covenants. For the measure of debt covenants we produce an index in which we cater for all debt contracts belonging to different firms based on covenants. This is done by simply counting the total number of covenants in public debt markets.

The relationship between covenants and the level of timely loss recognition can be measured (Basu, 1997) and accounting conservatism provides the cover that can be utilized by covenants in order to influence the impact of bad news on earnings. Therefore, we estimate the following equation:

$$
\begin{aligned}
y_{i} \frac{e_{i-1}}{e_{i}}=a_{0}+ & a_{1} g\left(R_{i}<0\right)+a_{2} R_{i}+a_{3} g\left(R_{i}<0\right) R_{i}+\beta_{0} \operatorname{COV}_{s}+\beta_{1} g\left(R_{i}<0\right) \operatorname{COV}_{s} \\
& +\beta_{2} R_{i} \operatorname{COV}_{s}+g_{i}\left(R_{i}<0\right) R_{i} \operatorname{COV}_{s}+\varepsilon_{i}
\end{aligned}
$$

Where $\mathrm{y}_{\mathrm{i}}$ is the year $\mathrm{i}$ is earnings, $e_{i-1}$ is the market value of stock at the end of the year $\mathrm{i}-1, \mathrm{R}$ is the annual return, and $\mathrm{g}$ is the indicator of function used as 1 when the argument is true otherwise $0 . \operatorname{COV}_{S}$ Indicate the number of debt covenant in a firm. To check the hypothesis H1, coefficient $\beta 3$ expected to be positive.

In order to check the hypothesis $\mathrm{H} 2$, we augment in the above equation to allow coefficient $\beta 3$ to accept different values before and after the issue of covenant. Those values would be 1 if the debt issue in the following year 
otherwise 0 . We will use variable AFD to evaluate the hypothesis $\mathrm{H} 2$ that is the firms that rely more on debt covenant, emphasis more on timely recognition of loss. Therefore, the estimated regression model would be:

$$
\begin{aligned}
y_{i} \frac{a_{i-1}}{e_{0}}+ & a_{1} g\left(R_{i}<0\right)+a_{2} R_{i}+a_{3} g\left(R_{i}<0\right) R_{i}+\beta_{0} \operatorname{COV}_{s}+\beta_{1} g\left(R_{i}<0\right) \operatorname{COV}_{s} \\
& +\beta_{2} R_{i} \operatorname{COV}_{s}+\beta_{3} g_{i}\left(R_{i}<0\right) R_{i} \operatorname{COV}_{s}+\delta_{0} A F D_{i}+\delta_{1} g\left(R_{i}<0\right) R_{i} \operatorname{COV}_{s} A F D_{i}+\varepsilon_{i}
\end{aligned}
$$

\subsection{Sample Data}

In this study, we collect the data from the non-financial companies listed on the Malaysian stock exchange Bursa Malaysia during the financial period 2008 to 2018. These firms belong to different non-financial business sectors, listed on the Malaysian stock exchange. This data does not include the data of financial institutions because it does not meet the criteria for empirical analysis. We did not include the data of firms whose core data is missing for example total assets, total debt, total sales, etc. There are more than 900 companies listed on the Malaysian stock exchange Bursa Malaysia. We selected 180 listed companies belonging to different business sectors along with an observation of 1980. Financial institutions and firms who haven't provided a complete annual report and those firms whose data is missing for the study variables are not included in our study in keeping with previous practice. Therefore, the results can be obtained using a simple equation and enhanced by adding different values of covenant in order to confirm the second hypothesis. The estimation of model is based on the data of 10 years, beginning from 5 -years prior and 5-years after of the issue of covenant, excluding the year of issuance. Our hypothesis H1 suggests that as the firm starts using debt covenant, its timely recognition of losses is more pronounced. Second hypothesis suggests that the more the firm depends on debt covenants, the greater the emphasis on loss recognition.

\subsection{Control Variables}

According to previous research, there are other factors that should be consider while evaluating the relationship between the dependent variable and the independent variable. These additional variables are called control variables. The control variable is the one which remains constant throughout the study. It is neither a dependent variable nor an independent but has some real importance because it plays an effective role to obtain the results. This study includes four control variables. First is PR1 which indicates the return on asset of the company while strictly practicing the accounting conservatism. PR1 is equals to the percentage of profit a company earns in relation to its total assets, which is commonly defined as net income divided by total assets. It is also known as the performance variable, used to evaluate the performance of the firm with respect to the research aspect. Second one is PR2 which indicates the return on equity of the firm in the presence of debt covenant. It is also considered as the measure of the financial performance of the firm. It is calculated by dividing the net income by shareholders' equity. Third one is LVR which indicates the variation of debt in firm after entering in the debt contract. Following the study of Sadiq \& Othman (2017), LVR is measured using the proportion of total assets which is financed by loans. Fourth one is AQ which is the indicator of the audit quality. If a firm employed one of the big four audit firm than the value would be one otherwise zero.

\section{Results}

\subsection{Descriptive Analysis}

The table below contains the descriptive analysis of debt covenants and accounting conservatism. These results are derived from the 11 years data of 180 listed companies on the stock exchange of Malaysia during the financial period of 2008 to 2018. These results are closest to the previous study of (Christensen et al., 2016). The mean value of dependent variable COV is 6.012 which is less than the mean value of (Christensen et al., 2016). The mean value of $\mathrm{R}$ which indicates the return of the firms is 0.382 which is closest to the mean value of (Watts and Zimmerman [1986]). The mean value of AFD is 0.671. The mean value of control variables PR1, PR2, LVR and AQ are 0.513, $0.426,0.303$ and 0.49 respectively. The mean value of DBIG4 indicates that around $49 \%$ of the firms are audited by big4 audit firms. 
Table 1. Descriptive analysis

\begin{tabular}{llll}
\hline Variables & MAX & MIN & MEAN \\
\hline COV & 10.517 & 2.41 & 6.012 \\
\hline R & 0.68 & 0.173 & 0.382 \\
\hline AFD & 0.816 & 0.341 & 0.671 \\
\hline PR1 & 0.781 & 0.291 & 0.513 \\
\hline PR2 & 0.661 & 0.243 & 0.426 \\
\hline LVR & 0.541 & 0.081 & 0.303 \\
\hline AQ & 1 & 0 & 0.49 \\
\hline
\end{tabular}

\subsection{Correlation Analysis}

Table 2 below provides the results of the Pearson correlation analysis. In this study we used Pearson correlation analysis to find the correlation between all the variables that are used in the research in order to get the required outcome. In this study the correlation between $\mathrm{COV}$ and $\mathrm{R}$ is positive with the value of 0.34 which indicates that as the use of covenant increase the returns of the firm also increases. The correlation between COV and AFD is positively significant with the value of $0.19^{* *}$ which is not a strong correlation. The correlation between COV and PR1 is also positive with the value of 0.19 and again it is not strong correlation. The correlation of COV and PR2 is positively significant but very weak with the value of $0.04 * * *$. The correlation between COV and LVR is negative with the value of 0.17 which shows that covenant and debt does not increase with each other. The relationship between COV and AQ is positive but have a very weak correlation with the value of 0.09 . Following correlation does not show any strong relationship of these variables.

Table 2. Correlation

\begin{tabular}{llllllll}
\hline Variables & COV & R & AFD & PR1 & PR2 & LVR & AQ \\
\hline COV & 1 & & & & & & \\
\hline R & 0.34 & 1 & & & & & \\
\hline AFD & $0.19^{* *}$ & -0.2 & 1 & & & & \\
\hline PR1 & 0.19 & $0.12^{* *}$ & -0.08 & 1 & & & \\
\hline PR2 & $0.04^{* * *}$ & 0.11 & -0.09 & 0.08 & 1 & & \\
\hline LVR & -0.17 & -0.13 & 0.09 & -0.13 & -0.19 & 1 & \\
\hline AQ & 0.09 & 0.02 & -0.25 & 0.12 & 0.02 & -0.12 & 1 \\
\hline
\end{tabular}

** Significant at the $1 \%$ level; * Significant at the $5 \%$ level respectively

\subsection{Regression Analysis}

The table below draw the regression results of debt covenant and accounting conservatism where timely loss recognition playing the part of accounting conservatism. Overall the results are positive and reflect our hypothesis favorably. The coefficient of intercepts is significantly equivalent $0.0529 * * *$ with the $\mathrm{t}$-stat of 23.6 and is consistent with the previous study of (Mulherin et al., 2018). However, coefficients of COV is positively significant and equal to $0.0028^{* *}$ with the t-stat of 2.49 . It implies that the increase in in use of covenant is directly relate with the timely recognition of loss and is consistent with our hypothesis $\mathrm{H} 1$. $\mathrm{R}$ has a significant and positive relationship with timely recognition of loss equivalent to $0.3784 * * *$ with the t-stat of 22.21 which indicates that profits of the firms are increasing with the adoption of accounting conservatism. The relationship of AFD and timely loss recognition is significantly positive with the value of $0.0107 * *$ along with the t-stat of 2.44 . This implies that Malaysian firms more emphasis on timely recognition of loss while using debt covenant. Hence are consistent with our hypothesis $\mathrm{H} 2$. DROA, DROE and DDEBT have a negative relationship with timely recognition of loss whereas, DBIG4 has a significantly positive relationship with timely recognition of loss. 
Table 3. Regression

\begin{tabular}{|c|c|}
\hline Variables & Timely loss Recognition \\
\hline \multirow{2}{*}{ Intercept } & $0.0529 * * *$ \\
\hline & 23.6 \\
\hline \multirow{2}{*}{$\mathrm{COV}$} & $0.0028 * *$ \\
\hline & 2.49 \\
\hline \multirow{2}{*}{$\mathbf{R}$} & $0.3784 * * *$ \\
\hline & 22.21 \\
\hline \multirow{2}{*}{ AFD } & $0.0107 * *$ \\
\hline & 2.44 \\
\hline \multirow{2}{*}{ PR1 } & 0.0027 \\
\hline & 1.36 \\
\hline \multirow{2}{*}{ PR2 } & -0.0152 \\
\hline & -1.35 \\
\hline \multirow{2}{*}{ LVR } & -0.0234 \\
\hline & -1.49 \\
\hline \multirow{2}{*}{ AQ } & $0.0061 *$ \\
\hline & 1.95 \\
\hline Adj. $R^{2}$ & 0.137 \\
\hline
\end{tabular}

** Significant at the $1 \%$ level; * Significant at the $5 \%$ level respectively

\subsection{Robustness Check}

The robustness test is based on the alternative model of Ball and Shivakumar measure of timely loss recognition. In this test we break the covenant into three categories along with the overall category which include the overall count of covenants in the contract which is indicated by OVRAL. First category is PCPL which is the principle component characterized by different types of covenant. Second category is POUT in which we measure the count of covenant which is restricted by payout. Third category is INTM which include the count of covenant related to investment projects especially mergers and acquisition.

Below results are consistent with our previous results except the second performance measure related to equity. Previous regression results were negative, and the results found by Ball and Shivakumar measure of timely loss recognition are positive. These results are also consistent with both our hypotheses.

Table 4. Asymmetric timeliness of earnings and the use of covenants

\begin{tabular}{lllll}
\hline Variables & OVRAL & PCPL & POUT & INTM \\
\hline \multirow{2}{*}{ Intercept } & $0.0571^{* *}$ & $0.0525^{* * *}$ & $0.0551^{* * *}$ & $0.0524^{* * *}$ \\
\cline { 2 - 5 } COV & 3.45 & 3.28 & 3.46 & 3.19 \\
\cline { 2 - 5 } & 0.0027 & 0.003 & 0.0026 & 0.0031 \\
\hline \multirow{2}{*}{$\mathbf{R}$} & 1.36 & 1.48 & 1.29 & 1.55 \\
\hline \multirow{2}{*}{ AFD } & $0.1518^{* *}$ & $0.1523^{* * *}$ & $0.1515^{* * *}$ & $0.1517^{* * *}$ \\
\cline { 2 - 5 } & 3.18 & 3.18 & 3.17 & 3.17 \\
\hline \multirow{2}{*}{ PR1 } & $0.0073^{* * *}$ & $0.0226^{* *}$ & $0.0116^{* * *}$ & $0.0198^{* * *}$ \\
\hline \multirow{2}{*}{ PR2 } & 3.44 & 2.81 & 3.28 & 2.69 \\
\cline { 2 - 5 } & 0.0061 & 0.0061 & 0.0061 & 0.0061 \\
\hline
\end{tabular}




\begin{tabular}{lllll}
\hline \multirow{2}{*}{ LVR } & -0.0234 & $-0.0271^{*}$ & -0.0229 & $-0.0285^{*}$ \\
\cline { 2 - 5 } & -1.49 & -1.74 & -1.47 & -1.85 \\
\hline \multirow{2}{*}{ AQ } & 0.0107 & $0.0264 * * *$ & 0.0136 & $0.018^{*}$ \\
\hline Adj. $\mathbf{R}^{\mathbf{2}}$ & 0.99 & 2.96 & 1.33 & 1.92 \\
\hline
\end{tabular}

** Significant at the $1 \%$ level; * Significant at the 5\% level respectively"

\section{Conclusion}

The results above explain how debt covenant plays a role in satisfying the requirements of accounting conservatism (Balsam et al., 2018). This study is consistent with the previous study of Beatty et al. [2008], which suggested that the requirement of accounting conservatism is not met by the conservative contractual adjustment. Our results suggest that the use of covenant does not compromise the timely recognition of losses. In fact, the timely recognition of losses is demanded by the covenant, otherwise any negative association may be expected between them. Moreover, timely loss recognition does not only relate to cases of distress but in relation with covenant it also provides the mechanism that assists in reducing agency conflict. In addition, this study only counts the number of covenants present in the debt contract. If we also consider the tightness with which the covenant is bonded, the results would be more appropriate.

This study finds the evidences that show the positive relationship of debt covenant and accounting conservatism. We use the regressing model of Basu [1997] in order to find the relationship of debt covenant and accounting conservatism. In this study time loss recognition plays a part of accounting conservatism as it is the main component of accounting conservatism. We found that, as the use of debt covenant increased the emphasis on timely recognition of loss also increases. We also found that those firms who rely more on debt covenants emphasis more on debt covenants in order to resolve debt issues and maintain their good reputation in the debt market. Hence both of our hypothesis is consistent with our results and close to the study of Nikolaev, (2010).

\section{References}

Balakrishnan, K., Watts, R., \& Zuo, L. (2016). The effect of accounting conservatism on corporate investment during the global financial crisis. Journal of Business Finance \& Accounting, 43(5-6), 513-542. https://doi.org/10.1111/jbfa.12206

Balsam, S., Gu, Y., \& Mao, C. X. (2018). Creditor Influence and CEO Compensation: Evidence from Debt Covenant Violations. The Accounting Review, 93(5), 23-50. https://doi.org/10.2308/accr-52013

Basu, S. (1997). The conservatism principle and the asymmetric timeliness of earnings1. Journal of Accounting and Economics, 24(1), 3-37. https://doi.org/10.1016/S0165-4101(97)00014-1

Bhaskar, L. S., Krishnan, G. V., \& Yu, W. (2017). Debt covenant violations, firm financial distress, and auditor actions. Contemporary Accounting Research, 34(1), 186-215. https://doi.org/10.1111/1911-3846.12241

Biddle, G. C., Ma, M. L., \& Song, F. M. (2016). Accounting conservatism and bankruptcy risk.

Callen, J. L., Chen, F., Dou, Y., \& Xin, B. (2016). Accounting conservatism and performance covenants: a signaling approach. Contemporary Accounting Research, 33(3), 961-988. https://doi.org/10.1111/1911-3846.12208

Charitou, A., Karamanou, I., \& Kopita, A. (2018). The determinants and valuation effects of classification choice on the statement of cash flows. Accounting and Business Research, 48(6), 613-650.

Chen, C. J., He, W., \& Lu, C. J. (2018). Bank Loan Covenants and Accrual Quality.

Christensen, H. B., Nikolaev, V. V., \& Wittenberg-Moerman, R. (2016). Accounting information in financial contracting: The incomplete contract theory perspective. Journal of Accounting Research, 54(2), 397-435.

Collins, D. W., Chen, W., \& Melessa, S. (2017). The Effect of Conditional Accounting Conservatism on the Predictive Ability of Accruals Components with Respect to Future Cash Flows.

De Franco, G., Vasvari, F. P., Vyas, D., \& Wittenberg Moerman, R. (2016). Similarity in bond covenants. Rotman School of Management working paper, 2288723.

Deng, S., Li, Y., Lobo, G. J., \& Shao, P. (2018). Loan sales and borrowers' accounting conservatism. Contemporary Accounting Research, 35(2), 1166-1194. https://doi.org/10.1111/1911-3846.12408 
Deslatu, S., \& Susanto, Y. K. (2018). Pengaruh Kepemilikan Managerial, Debt Covenant, Litigation, Tax and Political Costs dan Kesempatan Bertumbuh terhadap Konservatisma Akuntansi. EKUITAS (Jurnal Ekonomi dan Keuangan), 14(2), 137-151. https://doi.org/10.24034/j25485024.y2010.v14.i2.2127

Donovan, J., Frankel, R. M., \& Martin, X. (2015). Accounting conservatism and creditor recovery rate. The Accounting Review, 90(6), 2267-2303. https://doi.org/10.2308/accr-51045

Glover, J. C., \& Lin, H. H. (2018). Accounting conservatism and incentives: Intertemporal considerations. The Accounting Review, 93(6), 181-201. https://doi.org/10.2308/accr-52107

Hillier, D., Martínez, B., Patel, P. C., Pindado, J., \& Requejo, I. (2018). Pound of flesh? Debt contract strictness and family firms. Entrepreneurship Theory and Practice, 42(2), 259-282.

Hope, O. K., Thomas, W. B., \& Vyas, D. (2017). Stakeholder demand for accounting quality and economic usefulness of accounting in US private firms. Journal of Accounting and Public Policy, 36(1), 1-13.

Hu, C., \& Jiang, W. (2019). Managerial risk incentives and accounting conservatism. Review of Quantitative Finance and Accounting, 52(3), 781-813. https://doi.org/10.1007/s11156-018-0726-5

Khurana, I. K., \& Wang, C. (2015). Debt maturity structure and accounting conservatism. Journal of Business Finance \& Accounting, 42(1-2), 167-203. https://doi.org/10.1111/jbfa.12104

Kim, B. H. (2019). Debt covenant slack and ex-post conditional accounting conservatism. Accounting and Business Research, 1-24. https://doi.org/10.1080/00014788.2019.1663720

Kim, J. B., \& Zhang, L. (2016). Accounting conservatism and stock price crash risk: Firm-level evidence. Contemporary Accounting Research, 33(1), 412-441. https://doi.org/10.1111/1911-3846.12112

Lara, J. M. G., Osma, B. G., \& Penalva, F. (2016). Accounting conservatism and firm investment efficiency. Journal of Accounting and Economics, 61(1), 221-238. https://doi.org/10.1016/j.jacceco.2015.07.003

Le, T. B., Pavelková, D., Do, T. T. N., \& Ngo, M. V. (2017). Does foreign ownership impact accounting conservatism adoption in Vietnam?. Business and Economic Horizons (BEH), 13(1232-2017-2422), 287-294.

Li, W., He, T. T., Tang, G., \& Marshall, A. (2015). Accounting Conservatism-Does Ownership Structure Matter?. Retrieved from http://swfa2015.uno.edu/D_Corporate_Decision_Making/paper_62.pdf

Marín Salazar, D. A., \& Ilić, I. (2018). Accounting information and the structure of corporate debt covenants. Master's thesis, Universidad EAFIT.

Mulherin, J. H., Netter, J. M., \& Poulsen, A. B. (2018). Observations on research and publishing from nineteen years as editors of the Journal of Corporate Finance. Journal of Corporate Finance, 49, 120-124.

Nikolaev, V. V. (2010). Debt covenants and accounting conservatism. Journal of Accounting Research, 48(1), 137-176. https://doi.org/10.1111/j.1475-679X.2009.00359.x

Pittman, J., \& Zhao, Y. (2019). Debt Covenant Restriction, Financial Misreporting, and Auditor Monitoring. Contemporary Accounting Research. https://doi.org/10.1111/1911-3846.12579

Ruch, G. W., \& Taylor, G. (2015). Accounting conservatism: A review of the literature. Journal of Accounting Literature, 34, 17-38. https://doi.org/10.1016/j.acclit.2015.02.001

Sadiq, M., \& Othman, Z. (2017). Earnings manipulations in politically influenced firms. Corporate Ownership \& Control, 15(1), 65-71. https://doi.org/10.22495/cocv15i1art6

Saeed, M. B. (2018). Corporate Governance Mechanisms and Accounting Conservatism: Evidence from Pakistan. NICE Research Journal, 18-38. https://doi.org/10.1108/CG-05-2017-0108

Suleiman, S. (2017). Debt Contracting and Conditional Accounting Conservatism. Int J Account Res, 5(147), 2. https://doi.org/10.4172/2472-114X.1000147

Wang, H., \& Zhang, J. (2017). Fair value accounting and corporate debt structure. Advances in Accounting, 37, 46-57. https://doi.org/10.1016/j.adiac.2017.02.002

Xie, Y. (2015). Confusion over accounting conservatism: A critical review. Australian Accounting Review, 25(2), 204-216. https://doi.org/10.1111/auar.12061

Zhong, Y., \& Li, W. (2017). Accounting conservatism: A literature review. Australian Accounting Review, 27(2), 195-213. https://doi.org/10.1111/auar.12107 